\title{
Determination of Metallic Beryllium and Beryllium Carbide in Beryllium Metal
}

\author{
Walter A. Bergholz
}

\begin{abstract}
A method is described for the determination of metallic beryllium and beryllium carbide in beryllium metal. The beryllium metal is dissolved in potassium hydroxide solution at a controlled rate of solution. The liberated hydrogen and methane are burned with copper oxide in an atmosphere of nitrogen. The water and carbon dioxide formed are absorbed in magnesium perchlorate and ascarite, respectively, and determined by weighing. The metallic beryllium is calculated from the water, corrections being made for any calcium or aluminum present as impurities that also liberate hydrogen in caustic solution; in case beryllium carbide is determined, a correction may also be made for the water formed by the combustion of methane. The beryllium carbide is calculated as $\mathrm{Be}_{2} \mathrm{C}$ from the carbon dioxide formed.
\end{abstract}

\section{Introduction}

No methods were found in the literature for the simultaneous determination of metallic beryllium and beryllium carbide in beryllium metal in the presence of beryllium oxide. The similarity of aluminum and beryllium in a number of their reactions suggested a study of the work published about the determination of both metallic aluminum and metallic beryllium in the presence of the oxides.

Metallic aluminum in aluminum metal or powder may be estimated by dissolving the metal in alkali solution $[1,2]^{2}$ or in hydrochloric acid [3], and then measuring the volume of the liberated hydrogen or weighing it as water after combustion. Information on gas evolution methods as used for industrial products may be found in the literature [4 to 8]. Two methods of special interest are described, one consisting of reduction of ferric ion to the ferrous state while dissolving the sample in acid, followed by titration [9], and the other involving the passage of hydrochloric acid gas over the metal at an elevated temperature, followed by determination of chloride in the sublimate [10]. A correction for iron is made in both cases. Similar procedures based upon reduction of ferric iron by aluminum metal in the presence of acid or dealing with volatilization of aluminum chloride have been discussed [11 to 17].

The hydrogen evolution methods for the determination of metallic aluminum cited above do not describe a procedure for the estimation of and correction for aluminum carbide. Yu. A. Klyachko and M. A. Barkov [18], in an effort to establish conditions for the determination of the total free and combined carbon in aluminum, burned the methane that was formed in the reaction of aluminum carbide and an alkali solution. For the estimation of microgram quantities of carbon in aluminum, a conductometric determination of the absorbed carbon dioxide has been developed [19].

Before discussing some attempts to determine metallic beryllium and beryllium carbide by methods 1 Present address, United States Atomic Energy Commission, New Brunswick
Laboratory, New Brunswick, N. J.

2 Figures in brackets indicate the literature references at the end of this paper. applied to aluminum as described above, a few references and preliminary experiments should be mentioned. Information about the volatilization of beryllium metal in hydrogen at low pressures at temperatures where beryllium oxide is not volatile $[20,21,22]$ and facts revealed in certain metallurgical patents $[23,24,25]$, dealing with the reduction of beryllium oxide with carbon and hydrogen or with hydrocarbons indicate that it would be difficult to develop a method along these lines. The possibility of an indirect method to determine metallic beryllium plus beryllium carbide in the presence of beryllium oxide should be mentioned. If it is assumed that the total beryllium in the sample is made up only of the metal, its oxide, and carbide, the difference between the total beryllium minus the beryllium as oxide equals the sum of metallic beryllium plus beryllium as carbide. In section 3 the procedures to determine total beryllium and beryllium oxide [26, 27] are briefly described. The usefulness of the indirect method, however, is limited by certain facts [28] that will also be discussed in section 3. Attempts to oxidize metallic beryllium or to precipitate copper with metallic beryllium in a copper sulfate solution did not prove encouraging.

A few hydrogen evolution methods for the determination of metallic beryllium have been reported prior to this work. A procedure designed to measure the volume of hydrogen liberated by metallic beryllium when dissolved in alkali [29] gave only fair results. $^{3}$ With essentially the same method [30], Ayers claims an accuracy of \pm 0.3 percent beryllium.

A method for the determination of beryllium carbide in beryllium metal has also been developed by Brush Beryllium Co., (private communication of Oct. 19, 1948). This procedure is based upon the fact that beryllium carbide forms methane with hot alkali solution [31]. The liberated gases are burned with copper oxide in an atmosphere of helium, and the combustion products are absorbed. Only carbon dioxide is weighed.

The foregoing discussion reveals the existence of methods based upon the same general principle as

${ }^{3}$ An improved procedure has been described in a private communication of Dec. 1947, by Charles B. Sawyer, Brush Beryllium Co. 


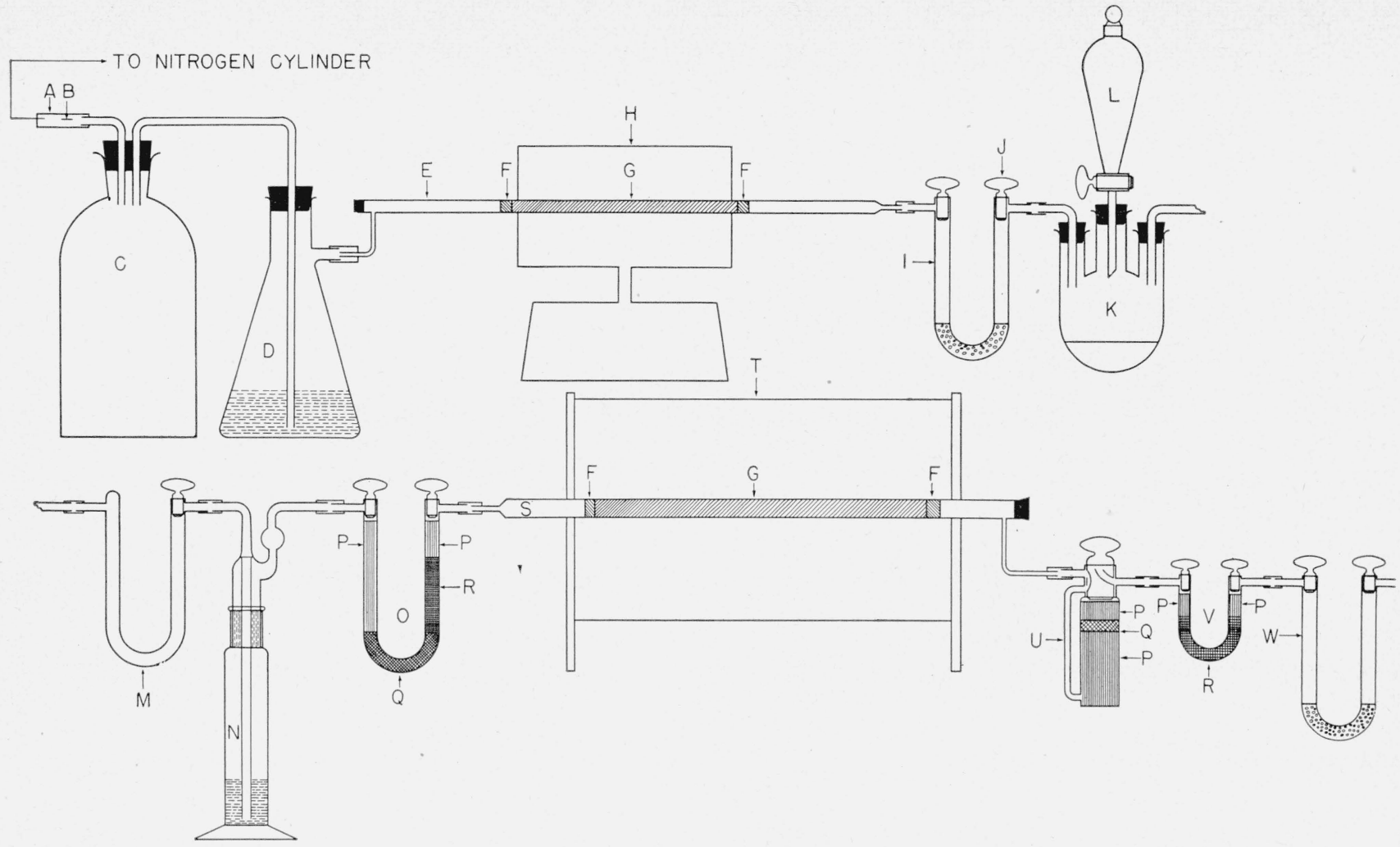

Figure 1. Apparatus for determination of metallic beryllium and beryllium carbide.

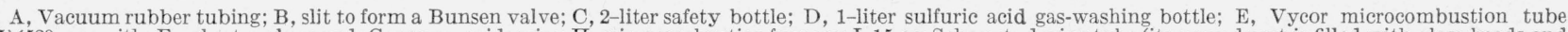

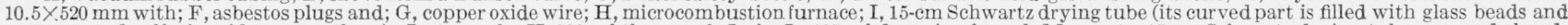

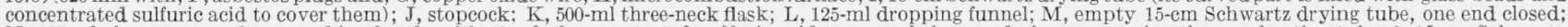

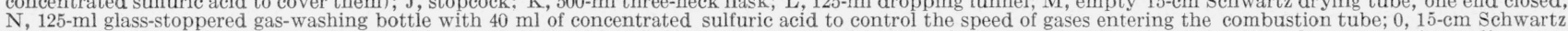

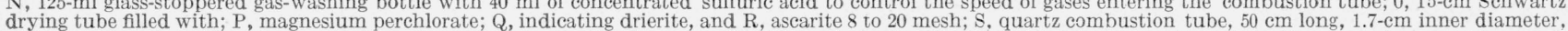

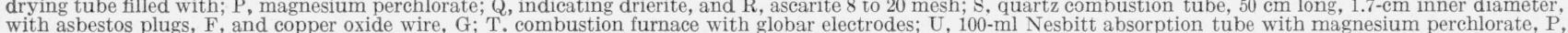

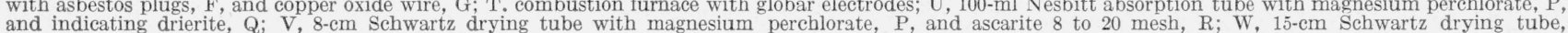
filled as tube I.

the procedure described in this paper. However, the methods so far described deal with the determination of the metal or the carbide only, whereas in this paper metallic beryllium and beryllium carbide are determined simultaneously. Furthermore, almost no information is available with respect to the precision obtained. The accuracy of the results obtained for metallic beryllium by hydrogen evolution methods is improved by correcting for the water derived from sources other than metallic beryllium. These sources are impurities such as metallic calcium, aluminum, and possibly magnesium, which liberate hydrogen; and beryllium carbide, which yields methane, when the sample is dissolved in caustic solution.

Beryllium carbide may be determined with increased accuracy by controlling the speed with which the sample is dissolved. Conditions under which the methane pressure is low enough to permit a complete combustion are described in section 2 .

\section{Procedure}

After the apparatus has been assembled as shown in figure 1 , the precombustion furnace is heated to about $800^{\circ} \mathrm{C}$, and the combustion furnace to $920^{\circ}$ $\pm 30^{\circ} \mathrm{C}$ (regulated by means of a Variac, type 100 \#Q, $2 \mathrm{KVA}$ ). Nitrogen is passed through the apparatus at a controlled speed of $60 \pm 10 \mathrm{ml} / \mathrm{min}$. The rate of flow is measured with a flowmeter, which is placed at the end of the train.

When all the air has been replaced by nitrogen in the absorption tubes and after the furnaces have reached the desired temperature, the absorption tubes are weighed with their stopcocks closed and then placed back in the train. Nitrogen is then passed through the system until the water blank is less then $0.0005 \mathrm{~g} / \mathrm{hr}$ and the carbon dioxide blank is less than $0.0002 \mathrm{~g} / \mathrm{hr}$.

When the blanks have attained a satisfactory state, $0.5-\mathrm{g}$ sample of metal is transferred to the reaction flask, $\mathrm{K}$, from a $5-\mathrm{ml}$ beaker. The system is flushed with nitrogen for 20 minutes in order to remove most of the air that entered the flask when the sample was added. Then stopcock, J, of the Schwartz drying tube, I, is closed. (Rubber connection, A, to nitrogen valve is provided with a slit, B, to form a Bunsen valve.) When the flow of gas bubbles through gaswashing bottle, $\mathrm{N}$, has practically ceased, the pressure in flask $K$ has decreased sufficiently to make it possible to add at once $30 \mathrm{ml}$ of hot water through 
the dropping funnel, L. This is followed by $150 \mathrm{ml}$ of hot potassium hydroxide solution $(100 \mathrm{~g}$ of potassium hydroxide dissolved in $100 \mathrm{ml}$ of water), which is added dropwise at a rate of 1 drop per second. A wire gauze with an asbestos center is placed underneath reaction flask $K$ and is heated intermittently and cautiously with a small flame while the caustic solution is added dropwise and until most of the sample has dissolved. Just enough heat is applied to maintain a gas flow of not more than four bubbles per second through the sulfuric acid gas-washing bottle. When most of the sample has dissolved, the nitrogen line is opened carefully, and the reaction is completed by boiling until a clear solution is obtained. The nitrogen pressure has to be high enough to avoid back pressure, which would cause losses, but not so high that the speed of flow of gas through the sulfuric acid gas-washing bottle, $\mathrm{N}$, exceeds four bubbles per second. When solution is completed the nitrogen flow is adjusted to $60 \pm 10 \mathrm{ml} / \mathrm{min}$ at the exit end of the train and is maintained at this rate for 2 hours. ${ }^{4}$ The absorption tubes are then weighed and placed back in the train for 1 hour to make sure that all combustion products are transferred to the absorption vessels.

The weight of the blank is deducted from the increase in weight of the absorption tube. Also, corrections are made for water derived from impurities (see section 3).

After four or five samples are analyzed, an appreciable amount of copper oxide has been reduced. When it is reoxidized, it usually cakes to some extent. It should therefore be replaced by a new filling, as a large surface area makes it easier to effect complete ignition of methane.

\section{Results}

As mentioned before, in calculating the result for metallic beryllium from the amount of water absorbed, the concentration of impurities has to be known in order to make the necessary corrections. Hence, the present method has been applied to seven samples of beryllium metal, A, B, C, D, E, F, and $\mathrm{G}$, for which analytical data were available. The impurities in samples A, B, C, and D were determined by chemical and spectrographic means [27]. With the exception of beryllium carbide, the impurities in samples E, F, and G were determined spectrographically at the Bureau. Beryllium carbide has been determined in samples $\mathrm{D}, \mathrm{E}, \mathrm{F}$, and $\mathrm{G}$, in the present work but not in samples $\mathrm{A}, \mathrm{B}$, and $\mathrm{C}$. The corrections involved would have been very small in the latter samples, as explained later.

Table 1 shows the amount of impurities. Of these, only the ones encountered in concentrations larger than 0.05 percent are included. All impurities of lower concentrations are omitted, since even if they

4]A test ignition of a given amount of methane from a cylinder of known purity was conducted in order to establish the proper conditions for complete combustion. When the temperature and the speed of flow were adjusted to that used for the blank, $99 \%$ or more of the theoretical amount of water and carbon dioxide were absorbed. Without speed control, appreciable amounts of methane were identified with the mass spectrograph by Fred $\mathrm{L}$. Mohler in the gases leaving the train when a sample that contained more than $1 \%$ of beryllium carbide was analyzed. would yield hydrogen or hydrocarbons in caustic solution, they would require only an insignificant correction, which is lower than the average deviation of the results.

\section{TABLE 1. Impurities in samples of beryllium}

\begin{tabular}{|c|c|c|c|c|c|c|c|}
\hline \multirow{2}{*}{ Element } & \multicolumn{7}{|c|}{ Sample } \\
\hline & A & B & $\mathrm{C}$ & D & $\mathrm{E}$ & $\mathrm{F}$ & G \\
\hline $\begin{array}{l}\mathrm{A} 1 \\
\mathrm{C}\end{array}$ & $\begin{array}{c}\% \\
0.09\end{array}$ & $\begin{array}{c}\% \\
0.21 \\
\text { a. } 19\end{array}$ & $\begin{array}{c}\% \\
1.22\end{array}$ & $\begin{array}{c}\% \\
0.23\end{array}$ & $\begin{array}{l}\% \\
0.09 \\
\text { (b) }\end{array}$ & $\begin{array}{l}\% \\
0.20 \\
\text { (b) }\end{array}$ & $\%$ \\
\hline & (b) & (b) & $\begin{array}{l}\text { (b) } \\
.36\end{array}$ & $\begin{array}{l}.18 \\
.06\end{array}$ & $\begin{array}{l}.34 \\
.20\end{array}$ & 1. 26 & .99 \\
\hline $\begin{array}{l}\mathrm{Cl} \\
\mathrm{Fe}\end{array}$ & & $\begin{array}{l}.61 \\
.07\end{array}$ & 30 & .09 & .08 & .09 & .10 \\
\hline $\mathrm{O}_{2}^{\circ} \ldots$ & .29 & d 2.70 & .35 & .70 & (b) & (b) & (b) \\
\hline $\begin{array}{l}\mathrm{Mg} \\
\mathrm{Si}\end{array}$ & & & $\begin{array}{l}.46 \\
.28\end{array}$ & .26 & & & \\
\hline $\mathrm{H}_{2} \mathrm{O}^{\circ} \ldots$ & .12 & f 2.65 & .19 & .30 & - & - & \\
\hline Total... & .56 & $\mathrm{~d} 6.43$ & 3.16 & 1.82 & & & \\
\hline
\end{tabular}

a 1-g sample plus $0.1 \mathrm{~g}$ of copper placed in an alundum boat lined with fine $\mathrm{R}$. $\mathrm{R}$. Alundum $\left(\mathrm{Al}_{2} \mathrm{O}_{3}\right)$, and then burned in oxygen at $1,200^{\circ} \mathrm{C}$.

b Not determined.

- Determined as beryllium oxide.

d This value is uncertain because of the presence of too much water, as explained later [28].

- Determined by heating the sample to $700^{\circ}$ to $800^{\circ} \mathrm{C}$ in an atmosphere of nitrogen and absorption with magnesium perchlorate.

Part of this water content is probably water of hydration of the $\mathrm{BeO}$ in the material as received in flake form.

From the impurities shown in table 1, only nonoxidized aluminum, calcium, magnesium, silicon, and beryllium carbide liberate gases that, upon combustion, yield water under the conditions of the test. Silicon has been assumed to be present in a combined form as no dark-brown residue of elementary silicon has been observed when dissolving the metal in hydrochloric acid. Iron does not react with potassium hydroxide solution (300 $\mathrm{g}$ of potassium hydroxide dissolved in $200 \mathrm{ml}$ of water) when it is boiled for 30 minutes.

Table 2 shows the corrections (in milligrams of water per gram of sample), assuming that $2 \mathrm{~g}$-atoms of aluminum yield $3 \mathrm{~g}$-moles of hydrogen, equivalent to $3 \mathrm{~g}$-moles of water; l g-mole of beryllium carbide yields $1 \mathrm{~g}$-mole of methane, equivalent to $2 \mathrm{~g}$-moles of water; $1 \mathrm{~g}$-atom of calcium and $1 \mathrm{~g}$-atom of magnesium each yield l g-mole of hydrogen, equivalent to $1 \mathrm{~g}$-mole of water.

TABLE 2. Corrections for water derived from impurities

\begin{tabular}{|c|c|c|c|}
\hline Sample & Impurity & & $\begin{array}{l}\text { Correction } \\
\text { (mg water/g } \\
\text { sample) }\end{array}$ \\
\hline & $\mathrm{Al}$. & $\begin{array}{l}\% \\
0.09\end{array}$ & 0.9 \\
\hline $\mathrm{B}_{\ldots}$ & $\mathrm{Al}$ & .21 & $\begin{array}{r}2.1 \\
12.2\end{array}$ \\
\hline $\mathrm{C}_{\ldots}$ & $\begin{cases}\mathrm{Am}- \\
\mathrm{Ca}\end{cases}$ & .36 & $\begin{array}{r}12.2 \\
1.6\end{array}$ \\
\hline & $\mathrm{Mg}_{\mathrm{Al}}$ & .46 & $\begin{array}{l}3.4 \\
2.3\end{array}$ \\
\hline $\mathrm{D}_{-}$ & $\mathrm{Be}_{2} \mathrm{C}$ & .18 & $\begin{array}{l}2.3 \\
2.2\end{array}$ \\
\hline & $\left\{\begin{array}{l}\mathrm{Ca} \\
\mathrm{Mg}\end{array}\right.$ & $\begin{array}{l}.06 \\
.26\end{array}$ & $\begin{array}{r}.3 \\
1.9\end{array}$ \\
\hline $\mathrm{E}$ & $\mathrm{Al}_{\mathrm{Be}-\mathrm{C}}^{\mathrm{Al}}$ & .09 & 9 \\
\hline & $\left\{\begin{array}{l}\mathrm{Be}_{2} \mathrm{C} \ldots \ldots \\
\mathrm{Ca} \ldots \ldots\end{array}\right.$ & $\begin{array}{l}.54 \\
.20\end{array}$ & $\begin{array}{r}4.1 \\
. \quad .9\end{array}$ \\
\hline $\mathrm{F}_{-}$ & $\{\mathrm{Al}$ & .20 & 2. 0 \\
\hline $\mathrm{G}_{-\ldots}$ & $\mathrm{Be}_{2} \mathrm{C} \ldots$ & $\begin{array}{r}1.20 \\
.99\end{array}$ & $\begin{array}{l}\text { 15. } 1 \\
11.9\end{array}$ \\
\hline
\end{tabular}


In samples $\mathrm{A}, \mathrm{B}$, and $\mathrm{C}$, beryllium carbide was not determined. The total carbon in each of these samples was found to be not greater than 0.19 percent, which is equivalent to 0.48 percent of beryllium carbide, if all of the carbon were present as $\mathrm{Be}_{2} \mathrm{C}$. The correction for $\mathrm{Be}_{2} \mathrm{C}$ would then be at the most $5.8 \mathrm{mg}$ (=2.9 mg Be, or $0.29 \%$ Be on basis $1 \mathrm{~g}$ ) of water per gram of sample, which is less than the deviations in the results sometimes encountered as shown in table 3 .

With the corrections for impurities computed as shown in table 2 , the results for metallic beryllium are tabulated in table 3 . The weights of sample used, the amounts of water absorbed, and the corrections for a blank are also included.

TавLE 3. Results for metallic beryllium

\begin{tabular}{|c|c|c|c|c|c|}
\hline Sample & $\begin{array}{l}\text { Weight of } \\
\text { sample }\end{array}$ & $\begin{array}{l}\text { Weight of } \\
\text { water } \\
\text { absorbed }\end{array}$ & $\begin{array}{l}\text { Correction } \\
\text { for blank }\end{array}$ & $\begin{array}{l}\text { Correction } \\
\text { for im- } \\
\text { purities }\end{array}$ & $\begin{array}{c}\text { Metallic } \\
\text { beryllium }\end{array}$ \\
\hline \multirow[t]{2}{*}{ A. } & \multirow[t]{2}{*}{$\begin{array}{l}m g \\
300.8 \\
299.9 \\
400.4 \\
400.7 \\
500.8 \\
500.6\end{array}$} & \multirow[t]{2}{*}{$\begin{array}{l}m g \\
596.8 \\
595.3 \\
792.5 \\
793.4 \\
994.6 \\
991.0\end{array}$} & \multirow[t]{2}{*}{$\begin{array}{r}m g \\
0.0 \\
.0 \\
.0 \\
.4 \\
1.0 \\
.4\end{array}$} & \multirow[t]{2}{*}{$\begin{array}{r}\quad m g \\
0.3 \\
.3 \\
.4 \\
.4 \\
.5 \\
.5 \\
\quad .5\end{array}$} & $\begin{array}{l}\% \\
99.3 \\
99.3 \\
99.1 \\
99.0 \\
99.3 \\
99.0 \\
\end{array}$ \\
\hline & & & & & 99.2 \\
\hline \multirow[t]{2}{*}{ B $\ldots$} & \multirow[t]{2}{*}{$\begin{array}{l}500.6 \\
500.0 \\
500.3 \\
500.4\end{array}$} & \multirow[t]{2}{*}{$\begin{array}{l}908.0 \\
908.4 \\
907.4 \\
910.8\end{array}$} & \multirow[t]{2}{*}{$\begin{array}{l}0.0 \\
.0 \\
1.5 \\
1.6\end{array}$} & $\begin{array}{l}1.1 \\
1.1 \\
1.1 \\
1.1\end{array}$ & $\begin{array}{l}90.7 \\
90.9 \\
90.5 \\
90.9\end{array}$ \\
\hline & & & & Avg & 90.8 \\
\hline \multirow[t]{2}{*}{ C } & \multirow[t]{2}{*}{$\begin{array}{l}500.4 \\
500.5 \\
500.5 \\
500.3\end{array}$} & \multirow[t]{2}{*}{$\begin{array}{l}977.7 \\
978.2 \\
977.0 \\
978.4\end{array}$} & \multirow[t]{2}{*}{$\begin{array}{r}1.1 \\
.8 \\
1.4 \\
1.4\end{array}$} & $\begin{array}{l}8.6 \\
8.6 \\
8.6 \\
8.6\end{array}$ & $\begin{array}{l}96.9 \\
96.9 \\
96.7 \\
96.9\end{array}$ \\
\hline & & & & Avg & 96.9 \\
\hline \multirow[t]{2}{*}{ D } & \multirow[t]{2}{*}{$\begin{array}{l}500.9 \\
501.8 \\
499.2 \\
498.9 \\
506.2\end{array}$} & \multirow[t]{2}{*}{$\begin{array}{l}980.8 \\
978.8 \\
976.2 \\
977.7 \\
987.4\end{array}$} & \multirow[t]{2}{*}{$\begin{array}{r}1.3 \\
.0 \\
2.0 \\
1.5 \\
.0\end{array}$} & $\begin{array}{l}3.4 \\
3.4 \\
3.3 \\
3.3 \\
3.4\end{array}$ & $\begin{array}{l}97.6 \\
97.3 \\
97.4 \\
97.6 \\
97.3\end{array}$ \\
\hline & & & & Avg $\ldots \ldots$ & 97.4 \\
\hline \multirow[t]{2}{*}{$\mathrm{E}$} & \multirow[t]{2}{*}{$\begin{array}{l}495.4 \\
445.7\end{array}$} & \multirow[t]{2}{*}{$\begin{array}{l}963.3 \\
868.4\end{array}$} & \multirow[t]{2}{*}{$\begin{array}{l}1.8 \\
1.2\end{array}$} & $\begin{array}{l}2.9 \\
2.6\end{array}$ & $\begin{array}{l}96.9 \\
97.1\end{array}$ \\
\hline & & & & Avg & 97.0 \\
\hline \multirow[t]{2}{*}{ F. } & \multirow[t]{2}{*}{$\begin{array}{l}499.5 \\
499.7\end{array}$} & \multirow[t]{2}{*}{$\begin{array}{l}967.6 \\
970.5\end{array}$} & \multirow[t]{2}{*}{$\begin{array}{r}0.0 \\
.0\end{array}$} & $\begin{array}{l}8.5 \\
8.5\end{array}$ & $\begin{array}{l}96.1 \\
96.4\end{array}$ \\
\hline & & & & $A v g$ & 96.3 \\
\hline \multirow[t]{2}{*}{ G. } & \multirow[t]{2}{*}{$\begin{array}{l}499.2 \\
499.1\end{array}$} & \multirow[t]{2}{*}{$\begin{array}{l}968.9 \\
966.5\end{array}$} & \multirow[t]{2}{*}{$\begin{array}{l}2.0 \\
2.1\end{array}$} & $\begin{array}{l}5.9 \\
5.9\end{array}$ & $\begin{array}{l}96.4 \\
96.2\end{array}$ \\
\hline & & & & Avg & 96.3 \\
\hline
\end{tabular}

Table 4 shows the results for beryllium carbide computed as $\mathrm{Be}_{2} \mathrm{C}$ from the amount of carbon dioxide absorbed, based on the assumption that $1 \mathrm{~g}$-mole of beryllium carbide is equivalent to $1 \mathrm{~g}$-mole of carbon dioxide.

As mentioned in the introduction, the amount of metallic beryllium may be computed by subtracting from the value for total beryllium, the sum of beryllium as oxide and beryllium as carbide, if these can be determined with reasonable accuracy, and provided that beryllium is not present in any other form.
TABLE 4. Results for beryllium carbide

\begin{tabular}{|c|c|c|c|c|}
\hline Sample & $\begin{array}{l}\text { Weight } \\
\text { of sample }\end{array}$ & $\begin{array}{l}\text { Weight } \\
\text { of carbon } \\
\text { dioxide }\end{array}$ & $\begin{array}{l}\text { Correction } \\
\text { for blank }\end{array}$ & $\begin{array}{l}\text { Beryllium } \\
\text { carbide }\end{array}$ \\
\hline D. & $\begin{array}{c}m g \\
506.2\end{array}$ & $\begin{array}{l}m g \\
1.3\end{array}$ & $\begin{array}{l}m g \\
0.0\end{array}$ & $\begin{array}{c}\% \\
\text { a } 0.18\end{array}$ \\
\hline \multirow[t]{2}{*}{$\mathrm{E}$} & $\left\{\begin{array}{l}495.4 \\
445.7\end{array}\right.$ & $\begin{array}{l}2.7 \\
2.5\end{array}$ & $\begin{array}{l}.3 \\
.3\end{array}$ & $\begin{array}{l}.33 \\
.34\end{array}$ \\
\hline & & & avg. & 0.34 \\
\hline \multirow[t]{2}{*}{$\mathrm{F}$} & $\left\{\begin{array}{l}499.5 \\
499.7\end{array}\right.$ & $\begin{array}{l}9.2 \\
9.2\end{array}$ & $\begin{array}{r}0.0 \\
.0\end{array}$ & $\begin{array}{l}1.26 \\
1.26\end{array}$ \\
\hline & & & avg.- & 1. 26 \\
\hline \multirow[t]{2}{*}{$\mathrm{G}_{\text {- }}$} & $\left\{\begin{array}{l}499.2 \\
499.1\end{array}\right.$ & $\begin{array}{l}7.0 \\
7.4\end{array}$ & $\begin{array}{r}0.0 \\
.0\end{array}$ & $\begin{array}{l}0.96 \\
1.01\end{array}$ \\
\hline & & & avg _.. & 0.99 \\
\hline
\end{tabular}

a The Brush Beryllium Co. reports $0.16 \%$, in a private communication of Oct. $19,1948$.

This has been done in table 5, making these two assumptions. The data in this table indicate that these assumptions are justified for the samples dealt with. The value cited for total beryllium and beryllium oxide have been obtained by applying procedures described in other investigations [26, 27]. These methods, in brief, are as follows: Total beryllium: The metal is dissolved in sulfuric acid. The silica is dehydrated by heating and filtered off. The other impurities are removed by oxine (8-hydroxyquinoline) precipitation at a $\mathrm{pH}$ of 4.5 . In the filtrate, the excess of oxine is destroyed and a slight excess of ammonium hydroxide solution is added. The precipitated beryllium hydroxide is converted to the oxide at $1,100^{\circ} \mathrm{C}$. Any silica in the beryllium oxide is then determined and its weight subtracted from the weight of beryllium oxide. Beryllium oxide: In the absence of water and oxygen, the metal is heated in hydrochloric acid to $600^{\circ} \mathrm{C}$, which volatilizes the metallic beryllium as chloride. The bervllium oxide is then determined in the residue colorimetrically with $-p$-nitrobenzene-azorcinol. If water is in the sample, the beryllium oxide values obtained are high. The longer the sample is dried, the lower are the beryllium oxide values obtained. If beryllium carbide $\mathrm{Be}_{2} \mathrm{C}$ is present in low concentrations, there is reason to believe that practically all of it is decomposed under the conditions of the test. According to Gmelin [31], anhydrous gaseous hydrochloric acid reacts slowly with the beryllium carbide $\mathrm{Be}_{2} \mathrm{C}$ at $600^{\circ} \mathrm{C}$, forming beryllium chloride vapor, carbon, and hydrogen.

TABle 5. Percentage of metallic beryllium computed and determined

\begin{tabular}{|c|c|c|c|c|c|}
\hline Sample & Total Be & $\begin{array}{c}\text { Be } \\
\text { computed } \\
\text { from BeO }\end{array}$ & $\begin{array}{c}\mathrm{Be} \\
\text { computed } \\
\text { from } \mathrm{Be} 2 \mathrm{C}\end{array}$ & $\begin{array}{c}\text { Computed } \\
\text { metallic } \\
\mathrm{Be}\end{array}$ & $\begin{array}{l}\text { Deter- } \\
\text { mined } \\
\text { metallic } \\
\text { Be }\end{array}$ \\
\hline $\begin{array}{l}\text { A } \ldots . . . \\
\text { B } \ldots . . \\
\text { C } \ldots \\
D_{\ldots} \ldots\end{array}$ & $\begin{array}{c}\% \\
99.5 \\
92.7 \\
96.8 \\
98.4\end{array}$ & $\begin{array}{l}\% \\
0.2 \\
1.5 \\
0.2 \\
.4\end{array}$ & $\begin{array}{l}\% \\
\text { (a) } \\
(\mathrm{a}) \\
(\mathrm{a}) \\
0.1\end{array}$ & $\begin{array}{c}\% \\
99.3 \\
91.2 \\
96.6 \\
97.9\end{array}$ & $\begin{array}{c}\% \\
99.2 \\
90.8 \\
96.9 \\
97.4\end{array}$ \\
\hline
\end{tabular}

a Not determined. 
Errors in the method of computing the corrections for water derived from impurities would affect the accuracy of the results. Such errors may occur because of the presence of part of the impurities in a combined form, for instance, as oxide, fluoride or nitride, or by segregation of the impurities, which would involve deviations from the average concentration used as the basis for the corrections applied. Inaccuracies would also be caused if part of the elemental impurities entered side reactions under the conditions of the procedure, leading to deviations from the theoretical amounts of water formed. It is, however, believed that none of these possible causes of error is significant, because, in the samples analyzed, the corrections are very small compared to the amount of water absorbed.

The assumptions about side reactions leading to deviations from the theoretical amount of methane formed are that, except for beryllium carbide, there is no other material present in the samples that yields hydrocarbons. It appears obvious that with the magnitude of impurities as low as encountered in the samples analyzed, this assumption can cause only a negligible error. Also, it has been assumed that $\mathrm{Be}_{2} \mathrm{C}$ is the only compound of beryllium and carbon present in the samples. According to Gmelin [31], $\mathrm{Be}_{2} \mathrm{C}$ and $\mathrm{BeC}_{2}$ are the only beryllium carbides known. $\mathrm{Be}_{2} \mathrm{C}$ is formed from the metal and carbon at elevated temperatures, whereas $\mathrm{BeC}_{2}$ is obtained in the reaction of beryllium powder with dry acetylene at $450^{\circ} \mathrm{C}$. This makes it probable that in beryllium metal the carbide present is $\mathrm{Be}_{2} \mathrm{C}$. The assumption that only methane is formed in the reaction between this carbide and potassium hydroxide is made because no other hydrocarbon has been mentioned in the literature as being formed in this reaction.

\section{Experiments with Hydrochloric Acid}

Hydrochloric acid dissolves the sample quickly and simplifies the technique, since the gas flow can be adjusted more easily. A larger sample, $1 \mathrm{~g}$ or more, can be analyzed. Metallic beryllium can be determined satisfactorily, but for beryllium carbide low results are obtained even if the gases do not pass through the combustion tube too fast.

The following procedure was used for the estimation of metallic beryllium: The apparatus and blank determinations are the same as previously described. The nitrogen pressure is adjusted to 1 bubble per second at the exit end of the train. Eighty-five milliliters of hydrochloric acid $(1+3)$ for a $0.5-\mathrm{g}$ sample is added through a dropping funnel at a speed of 20 drops per minute. When the sample has dissolved almost completely, the flow of nitrogen is increased to slightly more than 2 bubbles per second at the exit end of the train. Solution of the sample is completed by boiling. The determination is completed as outlined under section 2 .

Two determinations were carried out with sample A. The results obtained were 99.0 and 99.1 percent, which is about the same as those obtained in alkaline solution (99.2, table 3). Correction is made for the aluminum and iron in this sample.

\section{Summary}

Experimental data have been obtained that demonstrate metallic beryllium and beryllium carbide can be determined satisfactorily in beryllium metal by dissolving the material in potassium hydroxide solution, burning the liberated hydrogen and methane to water and carbon dioxide, and absorbing these products in magnesium perchlorate and soda-asbestos, respectively.

A limited number of experiments indicate that solution in hydrochloric acid yields satisfactory results for metallic beryllium, but gives low values for beryllium carbide.

\section{References}

[1] F. Schulze, Wagner's Jahresber. 10, 23 (1864).

[2] G. Klemp, Z. anal. chem. 29, 388 (1890).

[3] E. Kohn-Abrest, Compt. rend. 14\%, 1293 (1908), Bul. Soc. Chim. 5, 207 (1909).

[4] H. Hiller, Z. angew. chem. 33, I, 35 (1920).

[5] Julian H. Capps, J. Ind. Eng. Chem. 13, 808 (1921).

[6] Scott's Standard methods of chemical analysis, p. 90 (D. Van Nostrand Co., New York, N. Y., 1939)

[7] Julian H. Capps, J. Ind. Eng. Chem. 14, 81 (1922).

[8] M. G. Tikhmenev and V. P. Zvereva, Zavodskaya Lab. 10, 572 (1941).

[9] E. Kohn-Abrest, Ann. 9, 381 (1904) ; J. Chem. Soc. 86-II, 844 (1904); ASTM Methods chemical analysis of metals (1946); Chem. Anal. of Aluminum and its alloys (E $34-45)$, p. $146-47$.

[10] E. Kohn-Abrest, Compt. Rend. 149, 399 (1909).; Ann. chim. anal. app'l 14, 285 (1909).

[11] S. A. Pogadin, Minerali Syr'e Tsvetnye Metal. 4, 54 (1930)

[12] M. A. Shandorov, Tsvetnye Metal. 4, 672 (1930). Chimie \& Industrie 25, 37 (1930).

[13] Takayasu Harada, Anniversary Vol. Dedicated to Masumi Chicashige, 237-43 (1930).

[14] Friedrich L. Hahn, Z. chem. 80, 192 (1930).

[15] Hirsch Lowenstein, Z. anorg. allgem. chem. 199, 48 (1931).

[16] Friedrich L. Hahn, Z. anorg. allgem. chem. 204, 40 (1932).

[17] A. D. Mayants, Moscow Non-ferrous metal treatment plant, Zavodskaya Lab. 13, 619 (1947).

[18] Yu. A. Klyachko and M. A. Barkov, Zavodskaya Lab. \%, 148 (1938).

[19] H. R. Bolliger and W. D. Treadwell, Helv. chim. acta. 31, 1247 (1948).

[20] Fr. Fichter and E. Brunner, Z. Anorg. allgem. chem. 93, 86 (1915).

[21] P. Lebeau, Compt. rend. 123, 818 (1896).

[22] N. V. Phillips, Gloeilampenfabrieken, British patent 520434 (Apr. 24, 1940).

[23] Osias Kruk, Austrian patent, 153792 (July 11, 1938) (Cl. 409).

[24] Bengt R. F. Kjellgren and Charles B. Sawyer, of Brush Beryllium Co., U. S. Patent 2,204,221 (June 11, 1940).

[25] Helmut Schlecht and Michael Jahrstorfer, of Walter H. Duesberg, U. S. patent 2,242,759 (May 29, 1941).

[26] G. J. Petretic, Report NBS-C-100 of Dec. 1947, sections 2 and 6.1

[27] G. J. Petretic, Report NBS-C-101 of Dec. 1947.

[28] C. J. Rodden, Report NBS-C-103, of Jan. 1948, p. 4 to 5 and 7 to 8 .

[29] Unpublished work by C. J. Rodden and H. I. Feinstein, Report A-1492 (Oct. 1946)

[30] A. S. Ayers, Report CC-3257 (Sept. 20, 1946).

[31] Gmelin's Handbuch der Anorg. Chemie, 8 Auflage, System No. 26, Beryllium, p. 147 (1930).

1 References 26 to 30 may be obtained from the Library Branch of the Atomic Energy Commission, Oak Ridge, Tenn.

Washington, August 15, 1951. 